\title{
TINJAUAN TERHADAP PELAKSANAAN LEGAL DRAFTING (PENYUSUNAN PERATURAN PERUNDANG-UNDANGAN) DI TINGKAT DESA SESUAI UNDANG UNDANG NO 6 TAHUN 2014 TENTANG DESA
}

\author{
Oleh: \\ Ika Ariani Kartini \\ Fakultas Hukum Universitas Muhammadiyah Purwokerto \\ E-mail: ikarian.kartini@gmail.com
}

\begin{abstract}
Abstrak
Dalam tataran normatif, kebijakan publik sebagai sebuah proses dan keputusan politik menjelma menjadi proses dan penyusunan kaidah hukum yang nampak dari berbagai produk peraturan perundang-undangan. Oleh karena itu agar kebijakan publik dapat direspon oleh masyarakat dengan baik, maka partisipasi masyarakat dalam merusmuskan kebijakan publik itu harus diberi porsi yang memadai. Salah satu partisipasi masyarakat yang dimaksud adalah dengan melakukan advokasi terhadap kebijakan publik karena advokasi merupakan cara ampuh mempengaruhi pendapat publik atau orang lain, dan diharapkan juga dapat mengubah perilaku pemegang otoritas kebijakan yang tidak menguntungkan masyarakat. Dalam konteks kebijakan publik, maka advokasi dapat dimaknai sebagai upaya untuk memberikan pengaruh yang signifikan dalam pengambilan keputusan politik yang berkaitan dengan kebijakan publik yang dilakukan oleh pemegang otoritas pengambil keputusan. Oleh karena kebijakan publik itu menjelma dalam berbagai bentuk peraturan perundang-undangan (baik di tingkat pusat maupun daerah), maka membahas tentang strategi dan teknik advokasi kebijakan publik mau tidak mau bersinggungan dengan proses legalisasi yang dilakukan oleh badan atau pejabat yang diberi wewenang untuk membentuk peraturan Perundang-undangan tersebut.
\end{abstract}

Kata kunci: Kebijakan Publik, Peraturan Perundang-undangan, Partisipasi

\section{A. PENDAHULUAN}

Kedudukan Badan Permusyawaratan Desa (BPD) mengalami perubahan dengan ditetapkannya Undang-undang Nomor 6 Tahun 2014 tentang Desa. Jika sebelumnya BPD merupakan unsur penyelenggara pemerintahan maka sekarang menjadi lembaga desa. Saat ini fungsi BPD adalah menyalurkan aspirasi, merencanakan APBDes, dan mengawasi pemerintahan desa. Sedangkan tugasnya adalah menyelenggarakan musyawarah desa (musdes) dengan peserta terdiri kepala desa, perangkat desa kelompok, dan tokoh masyarakat. Jumlah pesertanya tergantung situasi kondisi setiap desa. Musyawarah desa berfungsi sebagai ajang kebersamaan dan membicarakan segala kebijakan tentang desa, termasuk juga dalam perumusan dan penyusunan peraturan desa. 
Keberadaan peraturan desa mulai dikenal sebagai salah satu bentuk peraturan perundang-undangan sejak diundangkannya Undang-Undang Nomor 22 Tahun 1999 tentang Pemerintahan Daerah sebagai salah satu tugas dari Badan Perwakilan Desa, sebuah badan yang dibentuk sebagai perwujudan demokrasi di tingkat desa. Teori perundang-undangan adalah serangkaian pemahaman-pemahaman, pendapat-pendapat yang tersusun secara sistematis, logis dan konkrit tentang hakekat keberadaan setiap keputusan tertulis yang dikeluarkan oleh pejabat yang berwenang dalam mengatur tingkah laku manusia yang bersifat dan berlaku mengikat umum, agar diperoleh kejelasan dan kejernihan yang bersifat kognitif. ${ }^{1}$

Pemberlakuan Undang-Undang tentang Pemerintahan Daerah yang baru melalui Undang-undang Nomor 32 Tahun 2004 tentang Pemerintahan Daerah tetap mengakui dan menguatkan peraturan desa meskipun tetap belum memberikan definisi atau batasan pengertian tentang apa yang dimaksud dengan peraturan desa. Menurut Undang-undang Nomor 31 Tahun 2004 tentang Pemerintahan Daerah, peraturan perundang-undangan di tingkat daerah adalah peraturan daerah, peraturan kepala daerah, dan keputusan kepala daerah. ${ }^{2}$ Definisi tentang Peraturan Desa disebutkan di dalam Pasal 1 Undang-undang Nomor 10 Tahun 2004 tentang Pembentukan Peraturan Perundang-undangan, yaitu peraturan perundang-undangan yang dibuat oleh Badan Perwakilan Desa atau nama lainnya bersama dengan kepala desa atau nama lainnya. Definisi ini juga yang digunakan oleh Peraturan Pemerintah Nomor 72 Tahun 2005 yang merupakan pengaturan lebih lanjut tentang desa.

Undang-undang Nomor 10 Tahun 2004 meletakkan Peraturan Desa menjadi salah satu jenis peraturan perundang-undangan di dalam hierarkhi yang digolongkan ke dalam salah satu bentuk peraturan daerah. Hal ini kemudian hari diakui sebagai sebuah kesalahan karena peraturan desa berbeda dengan peraturan daerah sehingga di dalam undang-undang tentang pembentukan peraturan perundang-undangan yang baru yaitu Undang-undang Nomor 12 Tahun 2011, peraturan desa dikeluarkan dari hierarkhi peraturan perundang-undangan,

I Gusti Ayu Ketut Rachmi Handayani, Formulasi Legal Drafting Perda, Jurnal EKOSAINS, Vol. III No. 1, Maret 2011.

2 B. Hestu Cipto Handoyo, 2008, Prinsip Legal Draft dan Desain Naskah Akademik, Universitas Atma Jaya, Yogyakarta. 
tetapi tetap diakui keberadaannya sebagai salah satu jenis peraturan perundangundangan dan mempunyai kekuatan hukum mengikat sepanjang diperintahkan oleh peraturan perundang-undangan yang lebih tinggi atau dibentuk berdasarkan kewenangan.

Adapun urusan pemerintahan yang menjadi kewenangan desa menurut Pasal 7 Peraturan Pemerintah Nomor 72 Tahun 2005 adalah:

1. urusan pemerintahan yang sudah ada berdasarkan hak asal usul desa;

2. urusan pemerintahan yang menjadi kewenangan kabupaten/kota yang diserahkan pengaturannya kepada desa;

3. tugas pembantuan dari Pemerintah, Pemerintah Provinsi, dan Pemerintah Kabupaten/Kota; dan

4. urusan pemerintahan lainnya yang oleh peraturan perundang-undangan diserahkan kepada desa.

Jika mengacu kepada Pasal 13 Undang-Undang Nomor 10 Tahun 2004 tentu saja materi muatan Peraturan Desa menjadi sangat luas, sedangkan pembagian urusan pemerintahan yang kemudian diatur di dalam Peraturan Pemerintah Nomor 38 Tahun 2007 hanya mengatur hingga Pemerintah Daerah Kabupaten/Kota, sehingga apa yang akan diatur oleh peraturan desa sudah sedemikian terbatas dan bergantung kepada pendelegasian atau tugas pembantuan dari pemerintahan di tingkat yang lebih tinggi. Mengacu pada pasal 7 Peraturan Pemerintah Nomor 72 Tahun 2005 tersebut maka artinya pemerintah desa tidak dapat begitu saja membentuk sebuah peraturan desa untuk menjabarkan sebuah peraturan perundang-undangan di tingkat lebih tinggi jika tidak ada perintah dari peraturan perundang-undangan atau pendelegasian karena urusan atau kewenangan asli yang diselenggarakan oleh desa sangat terbatas.

Materi muatan yang secara khusus disebut di dalam Peraturan Pemerintah Nomor 72 Tahun 2005 untuk ditetapkan dengan Peraturan Desa adalah pembentukan dusun atau dengan sebutan lain (Pasal 3), susunan organisasi dan tata kerja pemerintah desa (Pasal 12), APBDes (Pasal 61 dan 73), Rencana Pembangunan Jangka Menengah Desa (Pasal 64), Pengelolaan Keuangan Desa 
(Pasal 76), Pembentukan Badan Usaha Milik Desa (Pasal 78), dan Pembentukan Lembaga Kemasyarakatan (Pasal 89).

Kebutuhan pembangunan desa meliputi tetapi tidak terbatas pada kebutuhan primer, pelayanan dasar, lingkungan, dan kegiatan pemberdayaan masyarakat desa. ${ }^{3}$ Oleh karena itu, jenis dan ragam peraturan desa yang disusun dan ditetapkan bergantung pada kebutuhan penyelenggara pemerintahan di desa. Sehingga diharapkan kepada Pemerintah Desa dan BPD agar dapat mengidentifikasi topik-topik yang perlu dibuat sebagai peraturan desa. Tingkat kepentingan ini hendaknya dilihat dalam kerangka kepentingan sebagian besar masyarakat agar Peraturan Desa yang dibuat benar-benar aspiratif. Peraturan desa juga perlu dibuat karena adanya perintah atau keharusan yang ditetapkan melalui peraturan yang lebih tinggi. Peraturan desa seperti ini biasanya merupakan penjabaran dan pengukuhan dari peraturan yang lebih tinggi tersebut.

\section{B. PEMERINTAH DESA}

Pemerintah Desa terdiri dari Kepala Desa dan Perangkat Desa, sedangkan Perangkat Desa terdiri dari sekretaris desa dan perangkat lainnya, yaitu sekretariat desa, pelaksana teknis lapangan dan unsur kewilayahan, yang jumlahnya disesuaikan dengan kebutuhan dan kondisi sosial budaya setempat. Kepala Desa mempunyai tugas menyelenggarakan urusan pemerintahan, antara lain pengaturan kehidupan masyarakat sesuai dengan kewenangan desa seperti, pembuatan peraturan desa, pembentukan lembaga kemasyarakatan, pembentukan Badan Usaha Milik Desa, dan kerja sama antar desa, urusan pembangunan, antara lain pemberdayaan masyarakat dalam penyediaan sarana prasarana fasilitas umum desa seperti, jalan desa, jembatan desa, irigasi desa, pasar desa, dan urusan kemasyarakatan, yang meliputi pemberdayaan masyarakat melalui pembinaan kehidupan sosial budaya masyarakat seperti, bidang kesehatan, pendidikan serta adat istiadat.

3 http://www.worldcat.org/title/undang-undang-no-6-tahun-2014-tentang-desa-dilengkapipedoman-pengelolaan-keuangan-desa-pedoman-pengelolaan-kekayaan-desa-pedomanumum-tata-cara-pelaporan-dan-pertanggung-jawaban-penyelenggaraan-pemerintahan-desakerja-sama-desa-pengelolaan-pasar-desa-pakaian-dinas-kepala-daerah-wakil-kepala-daerahdan-kepala-desa-cadangan-pangan-pemerintah-desa-pembangunan-kawasan-perdesaanberbasis-masyarakat-persyaratan-dan-tata-cara-pengangkatan-sekretaris-desa-menjadipegawai-negeri-sipil-penyelenggaraan-perlombaan-desa-dan-kelurahan/oclc/878051103 


\section{BADAN PERMUSYAWARATAN DESA}

Badan Permusyawaratan Desa (BPD) berkedudukan sebagai unsur penyelenggara pemerintahan desa:

1. anggota BPD adalah wakil dari penduduk desa, berdasarkan keterwakilan wilayah yang ditetapkan dengan cara musyawarah dan mufakat;

2. anggota BPD terdiri dari Ketua Rukun Warga, pemangku adat, golongan profesi, pemuka agama dan tokoh atau pemuka masyarakat lainnya;

3. masa jabatan anggota BPD adalah 6 (enam) tahun dan dapat diangkat/ diusulkan kembali untuk 1 (satu) kali masa jabatan berikutnya;

4. jumlah anggota BPD berjumlah ganjil, minimal 5 (lima) orang maksimal 11 (sebelas) orang, berdasarkan:
a. luas wilayah;
b. jumlah penduduk, dan
c. kemampuan keuangan desa;

5. Peresmian anggota BPD ditetapkan dengan Keputusan Bupati/Walikota;

6. Sebelum memangku jabatannya, anggota BPD mengucapkan sumpah/janji secara bersama-sama di hadapan masyarakat dan dipandu oleh Bupati/Walikota;

7. Pimpinan BPD terdiri dari:
a. ketua (1 orang);
b. wakil ketua (1 orang);
c. sekretaris (1 orang).

\section{LEMBAGA KEMASYARAKATAN}

Berdasarkan Pasal 211 UU Nomor 32 Tahun 2004 dan Pasal 89 ayat (1) PP Nomor 72 Tahun 2005, di Desa dapat dibentuk Lembaga Kemasyarakatan, yang diatur lebih lanjut dengan Permendagri No. 5 Tahun 2007 tentang Pedoman Penataan Lembaga Kemasyarakatan. Lembaga Kemasyarakatan atau yang disebut dengan nama lain adalah lembaga yang dibentuk oleh masyarakat sesuai dengan kebutuhan dan merupakan mitra Pemerintah Desa dalam memberdayakan masyarakat. Lembaga Kemasyarakatan dapat dibentuk atas prakarsa masyarakat dan/atau atas prakarsa masyarakat yang difasilitasi 
Pemerintah melalui musyawarah dan mufakat.

Pembentukan Lembaga Kemasyarakatan Desa ditetapkan dalam Peraturan Desa dengan berpedoman pada Peraturan Daerah Kabupaten/Kota, berdasarkan pertimbangan bahwa kehadiran lembaga tersebut sangat dibutuhkan oleh masyarakat, maksud dan tujuannya jelas, bidang kegiatannya tidak tumpang tindih dengan lembaga yang sudah ada.

\section{E. BADAN USAHA MILIK DESA}

Dalam rangka meningkatkan pendapatan masyarakat dan desa, Pemerintah Desa dapat mendirikan Badan Usaha Milik Desa sesuai dengan kebutuhan dan potensi desa yaitu:

1. kebutuhan masyarakat terutama dalam pemenuhan kebutuhan pokok;

2. tersedia sumber daya desa yang belum dimanfaatkan secara optimal terutama kekayaan desa;

3. tersedia sumber daya manusia yang mampu mengelola badan usaha sebagai aset penggerak perekonomian masyarakat;

4. adanya unit-unit usaha masyarakat yang merupakan kegiatan ekonomi warga masyarakat yang dikelola secara parsial dan kurang terakomodasi, yang berbentuk badan hukum dapat berupa lembaga bisnis, yaitu unit usaha yang kepemilikan sahamnya berasal dari Pemerintah Desa dan masyarakat, seperti usaha mikro kecil dan menengah, lembaga keuangan mikro perdesaan (usaha ekonomi desa simpan pinjam, badan kredit desa, lembaga simpan pinjam berbasis masyarakat, lembaga perkreditan desa, lumbung pitih nagari dan sebagainya), dan ditetapkan dengan Peraturan Desa yang berpedoman pada Peraturan Daerah Kabupaten/Kota serta peraturan perundang-undangan.

Badan Usaha Milik Desa adalah usaha desa yaitu jenis usaha yang meliputi pelayanan ekonomi desa seperti:

1. usaha jasa yang meliputi jasa keuangan, jasa angkutan darat dan air, listrik desa, dan usaha lain yang sejenis;

2. penyaluran sembilan bahan pokok ekonomi desa;

3. perdagangan hasil pertanian meliputi tanaman pangan, perkebunan, peternakan, perikanan, dan agrobisnis; 


\section{F. KERJA SAMA DESA}

Berdasarkan Pasal 214 UU Nomor 32 Tahun 2004, dan Pasal 182 PP Nomor 72 Tahun 2005, terbitlah Permendagri Nomor 38 Tahun 2007 tentang Kerja Sama Desa. Desa dapat mengadakan kerja sama antar desa sesuai dengan kewenangannya, untuk kepentingan desa masing-masing dan kerja sama dengan pihak ketiga, dalam bentuk perjanjian bersama atau membentuk peraturan bersama. Apabila kerja sama tersebut membebani masyarakat dan desa harus mendapatkan persetujuan tertulis berdasarkan hasil rapat khusus dari BPD yang meliputi bidang pemerintahan, pembangunan, dan kemasyarakatan. Selain itu, dimaksudkan untuk kepentingan desa dalam rangka meningkatkan kesejahteraan masyarakat, serta bertujuan untuk meningkatkan kesejahteraan bersama dan mencegah ketimpangan antar desa yang berorientasi pada kepentingan dan aspirasi yang tumbuh dalam masyarakat.

Kerjasama Desa dengan pihak ketiga dapat dilakukan dalam bidang:

1. peningkatan perekonomian masyarakat desa;

2. peningkatan pelayanan pendidikan;

3. kesehatan;

4. sosial budaya;

5. ketentraman dan ketertiban;

6. pemanfaatan sumber daya alam dan teknologi tepat guna dengan memperhatikan kelestarian lingkungan.

Kerjasama Antar Desa ditetapkan dengan Keputusan Bersama Kerjasama Desa dengan pihak ketiga ditetapkan dengan Perjanjian Bersama. Penetapan Keputusan Bersama atau Perjanjian Bersama dimaksud dilakukan oleh pihakpihak yang melakukan kerjasama sesuai ketentuan yang berlaku. Penetapan Keputusan Bersama atau Perjanjian Bersama antara lain memuat:

1. ruang lingkup kerja sama;

2. bidang kerja sama;

3. tata cara dan ketentuan pelaksanaan kerja sama;

4. jangka waktu;

5. hak dan kewajiban;

6. pembiayaan; 
7. tata cara perubahan, penundaan dan pernbatalan;

8. penyelesaian perselisihan;

9. lain-lain ketentuan yang diperlukan.

\section{G. PERATURAN DESA}

Berdasarkan prinsip desentralisasi dan otonomi daerah, Desa atau yang disebut dengan nama lain diberi kewenangan untuk mengatur dan mengurus kepentingan masyarakat setempat berdasarkan asal usul dan adat istiadat setempat yang diakui dan dihormati dalam sistem Pemerintahan Negara Kesatuan Republik Indonesia. Dalam rangka pengaturan kepentingan masyarakat, maka guna meningkatkan kelancaran dalam penyelenggaraan, pelaksanaan pembangunan dan pelayanan kepada masyarakat sesuai dengan perkembangan dan tuntutan reformasi serta dalam rangka mengimplementasikan pelaksanaan UU Nomor 32 Tahun 2004, ditetapkanlah Peraturan Pemerintah No. 72 Tahun 2005 tentang Desa.

Peraturan Desa dibentuk dalam rangka penyelenggaraan Pemerintahan Desa, dengan demikian maka Peraturan Desa harus merupakan penjabaran lebih lanjut dari peraturan perundang-undangan yang lebih tinggi dan tidak boleh bertentangan dengan kepentingan umum dan/atau peraturan perundangundangan yang lebih tinggi, serta harus memperhatikan kondisi sosial budaya masyarakat desa setempat, dalam upaya mencapai tujuan pemerintahan, pembangunan dan pelayanan masyarakat jangka panjang, menengah dan jangka pendek. Peraturan Desa dibentuk berdasarkan pada asas pembentukan peraturan perundang-undangan yang baik (Pasal 2 Permendagri Nomor 29 Tahun 2006), meliputi:

1. kejelasan tujuan;

2. kelembagaan atau organ pembentuk yang tepat;

3. kesesuaian antara jenis dan materi muatan;

4. dapat dilaksanakan;

5. kedayagunaan dan kehasilgunaan;

6. kejelasan rumusan, dan

7. keterbukaan. 
H. MEKANISME PERSIAPAN, PEMBAHASAN, PENGESAHAN DAN PENETAPAN PERATURAN DESA

1. Rancangan Peraturan Desa diprakarsai oleh Pemerintah Desa dan dapat berasal dari usul BPD.

2. Masyarakat dan Lembaga Kemasyarakatan, berhak memberikan masukan terhadap hal-hal yang berkaitan dengan materi Peraturan Desa, baik secara tertulis maupun lisan terhadap Rancangan Peraturan Desa dan dapat dilakukan dalam proses penyusunan Rancangan Peraturan Desa.

3. Rancangan Peraturan Desa dibahas secara bersama oleh Pemerintah Desa dan BPD.

4. Rancangan Peraturan Desa yang berasal dari Pemerintah Desa, dapat ditarik kembali sebelum dibahas bersama BPD.

5. Rancangan Peraturan Desa yang telah disetujui bersama oleh Kepala Desa dan BPD selambat-lambatnya 7 (tujuh) hari sejak tanggal persetujuan bersama, disampaikan oleh Pimpinan BPD kepada Kepala Desa untuk ditetapkan menjadi Peraturan Desa, paling lambat 30 (tiga puluh) hari sejak diterimanya Rancangan Peraturan Desa tersebut.

6. Peraturan Desa wajib mencantumkan batas waktu penetapan pelaksanaan;

7. Peraturan Desa sejak ditetapkan, dinyatakan mulai berlaku dan mempunyai kekuatan hukum yang mengikat, kecuali ditentukan lain di dalam Peraturan Desa tersebut, dan tidak boleh berlaku surut.

8. Peraturan Desa yang telah ditetapkan, disampaikan oleh Kepala Desa kepada Camat sebagai bahan pembinaan dan pengawasan paling lambat 7 (tujuh) hari setelah ditetapkan.

9. Khusus Rancangan Peraturan Desa tentang Anggaran Pendapatan dan Belanja Desa, pungutan, dan penataan ruang, yang telah disetujui bersama dengan BPD.

\section{FAKTOR-FAKTOR YANG MENGHAMBAT HUBUNGAN KEPALA DESA DENGAN BPD DALAM PEMBENTUKAN PERATURAN DESA}

Dasar-dasar pertimbangan perlunya pembentukan peraturan hukum di tingkat desa yang baik semuanya tersirat atau dimuat dalam konsideran 
menimbang dan menetapkan. Pada konsideran menimbang memuat uraian singkat mengenai pokok-pokok pikiran yang menjadi latar belakang dari alasanalasan pembuatan peraturan hukum di desa. Dasar-dasar perlunya pengaturan memuat landasan sosiologis, filosofis, fisiologis, politis, ekonomis dan landasan yuridis.

Landasan yuridis memuat dasar hukum pembuat peraturan hukum daerah atau desa. Landasan yuridis dalam setiap peraturan hukum di tingkat daerah memuat landasan yuridis formil yaitu kewenangan membuat peraturan hukum daerah berdasarkan ketentuan dalam Undang-Undang Nomor 32 Tahun 2004 tentang Pemerintahan Daerah dengan perubahan Undang-Undang Nomor 12 Tahun 2008 tentang Pemerintahan Daerah. Pembentukan daerah dan landasan yuridis materi sifatnya tergantung dengan jenis peraturan hukum di daerah maupun di desa sebagai retribusi.

Materi muatan peraturan desa juga harus mengacu pada asas materi muatan peraturan perundang-undangan yang meliputi: pengayoman, kemanusiaan, kebangsaan, kekeluargaan, kenusantaraan, bineka tunggal ika, keadilan, kesamaan kedudukan dalam hukum dan pemerintahan, ketertiban dan kepastian hukum, dan atau keseimbangan, keserasian, dan keselarasan.

Materi yang terkandung di dalam peraturan desa merupakan seluruh materi dalam rangka penyelenggaraan urusan desa atau yang setingkat serta penjabaran lebih lanjut peraturan perundang-undangan yang lebih tinggi dan yang di dalamnya tidak diperbolehkan mengatur tentang ketentuan pidana. Termasuk penyelenggaraan urusan desa misalnya perdes APBDes, perdes susulan organisasi dan tata kerja pemdes, perdes tentang kedudukan keuangan kepala desa dan perangkat desa, dan lain-lain. Pada dasarnya perdes adaah kesepakatan-kesepakatan dari komponen-komponen masyarakat yang dituangkan dalam bentuk tertulis.

Kewenangan desa meliputi kewenangan dibidang penyelenggaraan pemerintahan desa, pelaksanaan pembangunan desa, pembinaan kemasyarakatan desa, dan pemberdayaan masyarakat desa berdasarkan prakarsa masyarakat, hak asal-usul, dan adat istiadat desa. Kewenangan desa meliputi kewenangan berdasarkan hak asal-usul, kewenangan lokal berskala desa, kewenangan yang ditugaskan oleh pemerintah, pemerintah daerah 
provinsi, atau pemerintah daerah kabupaten/kota, dan kewenangan lainnya yang sesuai dengan ketentuan peraturan perundang-undangan.

Pelaksanaan kewenangan berdasarkan hak asal-usul dan kewenangan lokal berskala desa diatur dan diurus oleh desa. Pelaksanaan kewenangan yang ditugaskan dan pelaksanaan kewenangan tugas lain dari pemerintah, pemerintah daerah provinsi, atau pemerintah daerah kabupaten/kota diurus oleh desa. ${ }^{4}$

Setiap jenis peraturan perundang-undangan memuat materi tertentu, yang satu berbeda dengan yang lainnya. Hal ini mengandung arti bahwa secara substansial pembedaan jenis suatu peraturan perundang-undangan tidak semata-mata didasarkan pada bentuk, syarat dan cara pembentukan, serta badan pembentukannya, tetapi juga didasarkan isi yang terkandung di dalamnya. Pada hakikatnya jenis peraturan perundang-undangan mencerminkan sebagai suatu wadah. Pembedaan suatu wadah disebabkan oleh pembedaan muatan yang diwadahi.

Sistem demokrasi dan negara hukum modern, sudah umum diketahui bahwa kekuasaan negara dibagi dan dipisah-pisahkan antara cabang-cabang kekuasaan legislatif, eksekutif, dan yudikatif. Pada pokoknya, kekuasaan untuk atau membuat aturan dalam kehidupan bernegara dikonstruksikan berasal dari rakyat yang berdaulat yang dilembagakan dalam organisasi negara di lembaga legislatif sebagai lembaga perwakilan rakyat. Sedangkan cabang kekuasaan pemerintahan negara sebagai organ pelaksana atau eksekutif hanya menjalankan peraturan-peraturan yang ditetapkan oleh cabang legislatif sementara itu, cabang kekuasaan kehakiman atau judikatif berpihak sebagai pihak yang menegakkan peraturan-peraturan itu melalui proses peradilan yang independen dan imparsial.

Penulis dalam hal ini dapat menarik kesimpulan bahwa faktor yang menghambat hubungan kepala desa dengan BPD dalam pembuatan peraturan desa tidaklah terlalu serius, mungkin hanya ada beberapa faktor sebagai berikut.

\footnotetext{
4 Ni'matul Huda, 2015, Hukum Pemerintahan Desa, Yogyakarta, Setara Press, hlm. 214.
} 
1. Evaluasi dari masyarakat

Dengan diadakannya public hearing dalam pembuatan rancangan peraturan desa dan memberikan kesempatan kepada masyarakat untuk ikut memberikan masukan dalam rancangan tersebut tidak jarang masyarakat memberikan masukan yang tidak sesuai dengan peraturan perundangundangan yang berlaku.

2. Waktu/kesibukan masing-masing anggota

Karena kesibukan masing-masing anggota BPD yang memang seperti kita ketahui anggota BPD memiliki pekerjaan tetap yang terkadang menjadi faktor pemhambat yang menyebabkan kesulitan untuk hanya sekedar berkumpul bersama dengan perangkat desa lainnya guna membahas program kerja terdekat maupun yang akan datang.

3. Kurangnya kemampuan/keterampilan Aparat Pemerintah Desa dalam mengoperasikan komputer

Faktor kemampuan/ keterampilan setiap aparat pada bidang tugas yang menjadi tugas dan tanggung jawabnya merupakan salah satu faktor penentu efektif tidaknya pelaksanaan tugas yang dibebankan kepadanya. Namun kenyataan menunjukkan bahwa faktor ini kurang dimiliki oleh setiap aparat, meskipun tingkat pendidikan formal setiap aparat dinilai cukup memadai, dimana dari jumlah 6 aparat yang terdiri dari Kepala Desa, Sekretaris Desa, 5 orang Kepala Bagian, 1 orang Kepala Urusan Tata Usaha, 9 orang Staf, dan 11 orang Anggota BPD menurut data/informasi yang disajikan dalam daftar monografi tidak ada yang memiliki latar belakang pendidikan cukup baik.

\section{J. KESIMPULAN DAN SARAN}

1. Kesimpulan

Desa dibentuk atas prakarsa masyarakat dengan memperhatikan asalusul desa dan kondisi sosial budaya masyarakat setempat. Pembentukan desa dapat berupa penggabungan beberapa desa, atau bagian desa yang bersandingan, atau pemekaran dari satu desa menjadi dua desa atau lebih, atau pembentukan desa di luar desa yang telah ada. 
Desa dapat diubah atau disesuaikan statusnya menjadi kelurahan berdasarkan prakarsa Pemerintah Desa bersama BPD dengan memperhatikan saran dan pendapat masyarakat setempat. Desa yang berubah menjadi Kelurahan, Lurah dan Perangkatnya diisi dari pegawai negeri sipil. Desa yang berubah statusnya menjadi Kelurahan, kekayaannya menjadi kekayaan daerah dan dikelola oleh kelurahan yang bersangkutan untuk kepentingan masyarakat setempat.

Desa mempunyai ciri budaya khas atau adat istiadat lokal. Kebijakan perencanaan pembangunan desa merupakan suatu pedoman-pedoman dan ketentuan-ketentuan yang dianut atau dipilih dalam perencanaan pelaksanakan pembangunan di desa yang mencakup seluruh aspek kehidupan dan penghidupan masyarakat sehingga dapat mencapai kesejahteraan bagi masyarakat.

Pembangunan masyarakat desa pada dasarnya adalah bertujuan untuk mencapai suatu keadaan pertumbuhan dan peningkatan untuk jangka panjang dan sifat peningkatan akan lebih bersifat kualitatif terhadap pola hidup warga masyarakat, yaitu pola yang dapat mempengaruhi perkembangan aspek mental (jiwa), fisik (raga), intelegensia (kecerdasan) dan kesadaran bermasyarakat dan bernegara. Akan tetapi pencapaian objektif dan target pembangunan desa pada dasarnya banyak ditentukan oleh mekanisme dan struktur yang dipakai sebagai sistem pembangunan desa.

2. Saran

Keberhasilan pembangunan dan pemberdayaan masyarakat serta tercapainya pelayanan prima di tingkat perdesaan, akan sangat tergantung kepada para pelaku pemerintahan desa sebagai masyarakat terpilih yang mempunyai kelebihan kemampuan untuk mengendalikan roda pemerintahan. Oleh karena itu diperlukan kesungguhan dalam penerapan pedoman dan peraturan perundang-undangan yang dibentuk dalam rangka penyelenggaraan Pemerintahan Desa 


\section{DAFTAR PUSTAKA}

\section{Buku}

Ilmar, Aminuddin, 2013, Hukum Tata Pemerintahan, Identitas Unhas, Makassar.

Handoyo, B. Hestu Cipto, 2008, Prinsip Legal Draft dan Desain Naskah Akademik, Universitas Atma Jaya, Yogyakarta.

Basri, Amaluddin, 1982, Administrasi Pembangunan Untuk Pembangunan Desa, Akademi Pembangunan Desa, Bekasi.

Hikmat, Harry, 2004, Strategi Pemberdayaan Masyarakat, Humaniora Utama Press, Bandung.

Miles, Matthew dan Huberman, A. Michael, 1992, Analisis Data Kuantitatif: Buku Sumber tentang Metode-metode Baru, UI Press, Jakarta.

Soekanto, Soerjono, 1990, Sosiologi Suatu Pengantar, PT: Raja Grafindo Persada, Jakarta.

Usman, Sunyoto, 2003, Pembangunan dan Pemberdayaan Masyarakat, Pustaka Pelajar, Yogyakarta.

Widjaja, HAW., 2002, Otonomi Daerah dan Daerah Otonom, PT. Raja Grafindo Persada, Jakarta.

\section{Sumber Lain}

Handayani, I Gusti Ayu Ketut Rachmi, Formulasi Legal Drafting Perda, Jurnal EKOSAINS, Vol. III No. 1, Maret 2011.

http://www.worldcat.org/title/undang-undang-no-6-tahun-2014-tentang-desadilengkapi-pedoman-pengelolaan-keuangan-desa-pedoman-pengelolaankekayaan-desa-pedoman-umum-tata-cara-pelaporan-dan-pertanggungjawaban-penyelenggaraan-pemerintahan-desa-kerja-sama-desa-pengelolaanpasar-desa-pakaian-dinas-kepala-daerah-wakil-kepala-daerah-dan-kepaladesa-cadangan-pangan-pemerintah-desa-pembangunan-kawasan-perdesaanberbasis-masyarakat-persyaratan-dan-tata-cara-pengangkatan-sekretarisdesa-menjadi-pegawai-negeri-sipil-penyelenggaraan-perlombaan-desa-dankelurahan/oclc/878051103 